\title{
The Changing Role and Strategies of the IMF and the Perspectives for the Emerging Countries
}

\author{
As mudanças no papel e nas estratégias do \\ FMI e as perspectivas para os países emergentes
}

FERNANDO J. CARDIM DE CARVALHO $* * * *$

\begin{abstract}
RESUMO: O FMI foi criado logo após a Segunda Guerra Mundial para gerenciar um sistema de pagamentos internacionais baseado em taxas de câmbio fixas. Nos seus primeiros anos, o remédio do Fundo para as crises da balança de pagamentos consistiu em reduzir a demanda agregada doméstica. Como resultado, suas políticas foram vistas como recessivas. Com o colapso do sistema de taxas de câmbio fixas no início dos anos 70, o Fundo perdeu seus clientes no mundo desenvolvido e voltou-se para os países em desenvolvimento. $\mathrm{Na}$ abordagem do Fundo, os países em desenvolvimento sofreram crises não por causa de desajustes temporários entre oferta e demanda agregadas, mas por problemas estruturais. Nesse sentido, o Fundo começou a impor reformas estruturais como condicionalidades para seus empréstimos, restringindo a autonomia dos países em desenvolvimento para adotar as políticas que considerariam favoráveis ao crescimento.

PALAVRAS-CHAVE: FMI; crise; estabilização; reformas estruturais.
\end{abstract}

ABSTRACT: The IMF was created right after World War II to manage an international payments system based on fixed exchange rates. In its early years the Fund's remedy to balanceof-payments crises consisted in reducing domestic aggregate demand. As a result, its policies were seen as recessive. With the collapse of the fixed exchange rates system in the early 70 s, the Fund lost its clients in the developed world and turned to developing countries. In the Fund's approach, developing countries suffered crises not because of temporary maladjustments between aggregate supply and demand but because of structural problems. Accordingly, the Fund began to impose structural reforms as conditionalities for its loans, curbing the autonomy of developing countries to adopt the policies they would see as favorable to growth.

KEYWORDS: IMF; crisis; stabilization; structural reforms.

JEL Classification: F34; F62.

\footnotetext{
* Professor of Economics, Institute of Economics, Universidade Federal do Rio de Janeiro - UFRJ, Rio de Janeiro/RJ, Brasil.E-mail: fjccarvalho@uol.com.br.

** Support from the National Research Council (CNPq) is gratefully acknowledged.
} 


\section{INTRODUCTION}

In 1944, when the end to World War Il was at hand, a conference was convened by the victorious countries in Bretton Woods, USA. The subject of the conference was the discussion of the reconstruction of the international economy after the war. Rules and procedures should be defined to organize international economic relations and institutions had to be created to enforce them. The decision to set an International Monetary Fund was one of the results of this conference.

The IMF, according to the first of its Articles of Agreement, aims at: To promote international monetary cooperation through a permanent institution which provides the machinery for consultation and collaboration on international monetary problems; (2) To facilitate the expansion and balanced growth of international trade, and to contribute thereby to the promotion and maintenance of high levels of employment and real income and to the development of the productive resources of all members as primary objectives of economic policy; (3) To promote exchange stability, to maintain orderly exchange arrangements among members, and to avoid competitive exchange devaluations; (4) To assist in the establishment of a multilateral system of payments in respect of current transactions between members and in the elimination of foreign exchange restrictions that hamper the growth of world trade; (5) To give confidence to members by making the general resources of the Fund temporarily available to them under adequate safeguards, thus providing them with opportunity to correct maladjustments in their balance of payments without resorting to measures destructive of national or international prosperity; (6) In accordance with the above, to shorten the duration and lessen the degree of disequilibrium in the international balances of payments of members. "

Despite all the good intentions of its founders, it did not take long for the IMF to be associated in the general public's minds with recessive policies, and foreign intrusion on domestic matters, particularly in developing countries. In recent years, this perception has been, if anything, strengthened, because a growing number of countries has been forced to ask the Fund's help but also because the IMF seems to have refocused its policies to deal more directly with what it sees as structure sources of external imbalances. Accordingly, the Fund is no longer satisfied with promoting fiscal balance, as it used to, as a condition to lend its money. Now it imposes the acceptance of the so-called structural reforms, touching practically all areas of the client economy.

In this paper, we want to examine the change in the IMF's view of its own role and mission, and the implications of this change for the client economies. Section 2 is then dedicated to identifying the original goals of the IMF. Section 3 deals with mainly with the IMF of the 1990s: how and why did it change its position as to adjustment strategies. Section 4 points out implications of this change for client economies. Section 5 closes the paper. 


\section{THE IMF: ORIGINAL GOALS AND STRATEGIES}

The purpose of the IMF was to manage the international payment system conceived in the Bretton Woods conference to be based on fixed exchange rates. The new payment systems should exhibit the virtues of the international gold standard, in particular the stability of exchange rates it entailed, without suffering its evils. These evils were identified by Keynes, one of the leading participants of the Bretton Woods conference, as being the asymmetric distribution of adjustment burdens among surplus and deficit countries that gave the gold standard its intrinsic recessive nature.

Under the gold standard, countries presenting deficits in their external accounts should bear the whole burden of adjustment, while surplus countries could just sit on their hands. Deficit countries had to contract their economies to reduce their imports while surplus countries were not expected to increase their own imports, which could relieve the sacrifice to be made by deficit countries. In other words, surplus countries could hoard their excess export revenues, reducing global demand and forcing the deficit country into unemployment. In contrast, an expansive adjustment would pressure surplus countries into spending hoards, increasing their demand for imports, helping the deficit countries to grow out of their deficits.

To involve surplus countries in the adjustment process was one of the main goals of Keynes' Bancor Plan. The Keynes plan consisted in the creation of an International Clearing Union, of which only central banks would be members, to record and clear all international payments in a monetary unit created only for this purpose, the bancor. The ICU would operate as a bank for central banks and would be able, as the IMF, to extend credit to members in difficulties. Its more interesting aspect, however, was that, to eliminate balance of payments imbalances, the Union would be guided by the principle that for every deficit there has to be a surplus somewhere in the system, so the burden of the adjustment would be shared by both surplus and deficit countries. Deficit countries would have to take measures to reduce their absorption of foreign goods at the same time in which surplus countries would have to increase their demand for foreign goods. If a surplus country failed to contribute to the adjustment, its deposits at the Union would be fined, and the receipts of fines would help to relieve the burden falling on deficit countries.

Keynes' plan aimed at promoting orderly conditions to support a growing volume of trade. Capital movements, in contrast, were seen as intrinsically disruptive, and the solution envisaged to deal with them was to adopt controls ${ }^{1}$. In fact, as noted by Boughton (1997), the American team participating in the conference,

\footnotetext{
${ }^{1}$ Already in one of the earliest drafts of Keynes' proposals for international monetary reform in the post war period he stated: "I share the view that control of capital movements, both inward and outward, must be a permanent feature of the post-war system[...]" (CWJMK: 25, p. 86).
} 
led by Harry White, took the same view. As stated by Boughton (1997), "article VI of the Articles of Agreement reflects those views. “

When the conference ended and an agreement was finally arrived at, it was not however, the International Clearing Union that was created but the International Monetary Fund. Gone were the mechanisms that would ensure that countries could grow out of trade deficits, their place taken by the traditional policies of austerity and recession to punish them for "living beyond their means." Keynes, while pushing for the approval of the agreement by the British government, was however pessimistic about the newly created institution: "the Fund can scarcely be, at any rate in the early years, the nucleus of a super-central bank, such as we hoped. Indeed, the main point for London to realize clearly is that the two institutions ${ }^{2}$ have become different from what we were expecting when we came away from Bretton Woods.” (CWJMK: 26, p. 232, Keynes' emphasis)

\section{The IMF’s Original Mission}

The Bretton Woods conference set up an international monetary system based on fixed exchange rates. The function of the IMF was to manage the payments system between countries in order to guarantee that current account imbalances emerging in any country's external transactions could not accumulate to threaten the fixed exchange rates regime. The IMF only cared for current account transactions. Capital account operations should be controlled by the member countries themselves, imposing controls if necessary to prevent the creation of any pressures on exchange rates because of capital flows between the members. If capital movements were kept under control, external imbalances could arise either because of mismanaged aggregate demand policies or because the exchange rates set when the agreement was signed were inconsistent with underlying fundamentals. In the first case, demand policies had to be brought into line, raising interest rates to reduce private demand and cutting fiscal deficits. If exchange rates, on the other hand, were "wrong", a fundamental disequilibrium could be recognized by the IMF and a correction of the rate authorized.

Most current account imbalance episodes, however, were diagnosed as resulting from excess aggregate demand, and the deficit countries were thus invited to take the necessary fiscal measures to bring their external transactions into balance. While the proper measures were being implemented and given the delays between their implementation and the emergence of results, the IMF would lend money to the deficit country to prevent any disruption in international trade. A running joke had it that focusing on government expenditures as the root of current account problems and on cuts of fiscal deficits as a solution led many to think that the acronym IMF stood for it's Mainly Fiscal.

In this period, IMF policies were already seen as recessive, since only current

\footnotetext{
${ }^{2}$ Keynes refers to the IMF and the World Bank.
} 
account deficits were seen to be a problem ${ }^{3}$. As a result, the solution always consisted in reducing aggregate demand to reduce imports and to free domestic goods for export. For developed countries, IMF policies created some discomfort in the short-term, in the form of lost output and rising unemployment, but these were mainly temporary effects. As for underdeveloped countries, this recipe was more dangerous because many times excess fiscal expenditures consisted in investment spending. A cut in government expenditures did not hit only running expenses but had also long-term effects. Resisting having to appeal to the Fund was seen, thus, as defending the possibility of economic development that the Fund's orthodoxy seemed ready to sacrifice.

\section{The IMF After Bretton Woods}

The Bretton Woods agreement was abandoned in the early 1970s. Floating exchange rates became the regime of choice, raising exchange rate volatility sharply, disrupting international trade and finance. In this period, the IMF seemed to be an institution that survived its usefulness. Created to defend stable (if not necessarily fixed) exchange rates, it was now powerless against bouts of volatility that surged repeatedly.

Excess volatility, of course, was undesirable even if stable rates could no longer be achieved. Trade would be reduced in the face of increased exchange rate uncertainties, and inflationary pressure could be generated if devaluations were too intense. This meant only, however, that most countries were not prepared to let rates float without control. In fact, dirty floating was the chosen regime, not free floating ${ }^{4}$. Developed countries frequently took the initiative of coordinating exchange rate policies but they did it in small groups, without appealing to the IMF and so avoiding the nuisance of having to listen, if nothing else, to underdeveloped countries.

In fact, as noted by Masson \& Mussa (1997), in this period, "IMF financing of payments imbalances of the industrial countries, in support of established or adjusted exchange rate pegs, generally ceased, and, over time, the focus of IMF financial support shifted to developing countries." As the authors inform, "the last IMF-supported programs for industrial countries were implemented in Italy and the United Kingdom in 1977, after the general move to floating exchange rates” (id., footnote 7).

Focussing on developing countries did not cause any immediate change in the Fund's views as to the causes and remedies for balance of payments crises. Even in the aftermath of the great crisis of 1982, initiated by the bankruptcy of Mexico,

\footnotetext{
${ }^{3}$ Paul Davidson (private correspondence) has pointed out that both quantity theorists like Harry Johnson and Keynesian economists like J. Tobin, P. Samuelson, J. Robinson and N. Kaldor believed that trade imbalances could only be due to excessive aggregate demand.

4. This should not be construed as meaning that freely floating exchange rates would solve the problem of volatility.
} 
followed by Brazil and other developing countries, "adjustment programs were not supported by the structural reforms that were needed to put the countries on a sustainable growth path. It was not until the mid-80s that the Fund and the indebted countries together moved to a more broadly based strategy of structural reform " (Boughton: 1997, 19).

A wholly different picture emerges from the examination of the adjustment programs negotiated by the Fund in the 90s. Currently, the Fund's help is made conditional mostly on the so-called structural reforms rather than on the immediate measures of fiscal restraint. In fact, as we saw in the case of the East Asian countries that were put under the IMF's care after the 1997 crisis, fiscal restraint could even be temporarily abandoned if structural reforms were being implemented as a condition for continuing support from the Fund. What caused this radical change of attitude on the part of the IMF?

\section{THE IMF IN THE 1990 S}

During the 1990s, the virtues of stable, if not fixed, exchange rates have been rediscovered by a large number of countries. Although floating exchange rates still define the relationship between the most important currencies in the world, that is, between the US dollar, the Deutsche Mark (in fact, nowadays the euro), and the Japanese yen, many countries adhered to fixed rates, at least among some currencies or tried to stabilize their exchange rates. Among the latter, we count a large number of developing countries seeking to use stable exchange rates either to anchor domestic prices as a means to control inflation or to reduce trade uncertainties for export-oriented economies. In this framework of fixed or semi-fixed exchange rates, the IMF would find a fertile ground to thrive again.

The current international environment is different in fundamental ways, however, from the one in which the Fund was created and its mission defined. International financial capital flows practically unimpeded in all but a few countries; private capital flows amply predominate over public and multilateral capital flows, mainly in the form of portfolio investment (in debt securities and equities); and a deeply conservative anti-government ideology set roots in most Western societies, leading to privatization initiatives, deregulation of private activities, and generally to a retreat of the state from the economic scene ${ }^{5}$.

\footnotetext{
${ }^{5}$ The IMF technicians identify a somewhat different picture. According to Masson \& Mussa (1997), the relevant changes were the adoption of floating exchange rates, the growth in size and agility of private capital flows, increasing trade and financial integration between countries and the expansion in the IMF membership. The main factor remains, however, that "not only did the magnitude of inflows increase during this period, but their composition changed fundamentally. In particular, private market sources more than accounted for the surge in capital flows [...J Moreover, while in earlier periods private sector lending had mainly been in the form of bank lending, the new surge in capital flows consisted primarily of portfolio investment, with increasing direct investment also playing a role" (Camdessus, 1995).
} 
In this new context, IMF's views on capital controls suffered a dramatic reversal. On the one hand, the Fund began to doubt both the efficacy and the desirability of capital controls; on the other, it paid much closer attention to the efficiency of domestic financial sectors in dealing with increasing volumes of resources. Accordingly, the IMF began to champion the cause of financial liberalization, to allow free international circulation of capital of any nature, pushing for the dismantling of existing controls and restrictions on exchange and financial operations. To improve the efficiency of financial sectors in developing countries, the Fund started to propose their opening to foreign banks. Finally, riding the conservative antistatist wave initiated in the 80 s, the Fund went beyond its original reservations as to the degree of intrusion on domestic policies of client economies to directly support changes in the domestic apparatuses of economic policy of these economies. It cannot escape to attention that this change in the IMF's views of the virtues of free international financial markets has brought them much closer to the views sponsored by the US Treasury ${ }^{6}$.

\section{The IMF and Financial Integration}

Having made this radical reassessment of the costs and benefits of restraining capital flows, the IMF has in fact assumed as its mission to take the process of financial integration to its completion. This actually became an official aim in the 1997 IMF meeting in Hong Kong, in which the Interim Committee that sets priorities for the Fund's actions decided to propose an amendment to the Articles of Agreement to pursue convertibility of capital account transactions. If the Articles of Agreement are effectively changed to establish convertibility of capital account transactions the dismantling of capital controls can become a new conditionality for obtaining the Fund's financial help?

\footnotetext{
${ }^{6}$ In fact, the excessively close identity between the two organisms has been recently denounced by The Economist: "In recent years the Fund and the [World Bank have been hijacked by their major shareholders for overtly political ends. Whether in Mexico in 1994, Asia in 1997 or Russia throughout the 1990s, the institutions have become a more explicit tool of western, and particularly American, foreign policy" (September 18, 1999). Lawrence Summers, then Deputy Secretary to the Treasury of the United States, currently Secretary of the Treasury, in a speech defending the increase of the US contribution to the Fund, stated that "In the past five years the United States has used its leadership role to achieve major improvements at the IME [...1 First, we have worked to adapt the IMF's policies and practices to meet the needs of a more integrated and market-driven global economy - to ensure that IMF will no longer stand for "It's Mainly Fiscal". In the same speech, according to Summers, "if there was no IMF $1 . .$. I there would be no multilateral vehicle for conditioned reform, reform which has achieved more trade liberalization in Asia in the past few months than many years of trade negotiation in the region" (Summers, 1998c).

${ }^{7}$ Accordingly, the US Treasury Secretary Lawrence Summers, this may not be a big deal: "Under the
proposed approach, countries will accept the obligation to liberalize the capital account fully, but what
that means precisely will be up to them to decide in cooperation with the IMF. Until they are ready, they
could avail themselves of transitional arrangements as approved by the Fund. They would simply have
to commit not to backtrack without IMF approval" (Summers, 1998). Of course, for counties depending
} 
For the Fund there can be no doubt that the benefits of financial globalization outweigh its costs. Somewhat paradoxically, however, costs and risks of global financial integration are identified in much richer detail than its benefits. The latter, in fact, are conceived mostly in terms of abstract qualities attributed to a theoretical (or ideological) notion of how free, unhindered markets would ideally operate ${ }^{8}$. Perfectly integrated global financial markets should allow capital to be allocated to its most productive uses. Developing countries should particularly profit from integration, since capital in these economies is scarcer than in the industrial countries, because they offer ampler opportunities for investment. Imperfections that are usually identified to distort financial market operations are widely ignored ${ }^{9}$.

Financial integration and removal of controls are also defended on a different basis. Markets may not be that efficient, but controls are assumed to be ineffective in actually constraining capital movements. The argument, in fact, appeals to the often-quoted but rarely demonstrated notion that recent financial innovations have made it impossible for anyone to tell one type of financial application from another.

In particular, it is proposed that among the types of short-term flows it became impossible to distinguish capital flows destined to finance international trade from speculative flows. In addition, because of possibilities opened by the derivatives markets, short-term capital and long-term capital were also no longer distinguishable. As a result, trying to discriminate and impede the free circulation of capital to filter "good" capital, holding "bad" capital away would be useless and could in the end penalize the host economy. It is even argued that "good" capital investors, that is, those interested in long-term investments will avoid those economies in which there were restrictions to short-term capital flows because the investors would be afraid one day the restrictions could be used against them ${ }^{10}$.

The fragility of the evidence on the actual benefits of globalization and on the deleterious effects of controls become particularly clear in the reply by IMF Deputy Director Stanley Fischer to criticisms like those of Rodrik (1998), who could find no evidence of a negative association between controls and growth and inflation in a sample of countries. According to Fischer, "it has been argued that neither theory nor evidence supports the view that international capital flows are potentially beneficial. The theoretical case, at the simplest level (with a relabelling of axes)

on the IMF help, the negotiation about "transitional arrangements" may be much tougher than for those just "consulting" with the Fund.

${ }^{8}$ For example, in statements like the following: "The increasing international integration of financial markets in the past 10-15 years has brought great benefits, by fostering a more efficient allocation of savings and boosting investment and growth in many countries" (Camdessus, 1995b). In other occasions, these benefits are acknowledged to be a "promise" (Camdessus, 1999b). As to the evidence to sustain this assessment, see the quotation from Fischer (1999), below.

${ }^{9}$ Cf. Greenwald \& Stiglitz (1984).

${ }^{10}$ Cf. Boughton (1997: 8-9). The condemnation of capital control is shared by the US Treasury. See Summers $(1998 ; 1998 b)$. 
is the same as the case for free trade. [...] At this stage there is little empirical evidence bearing on the benefits or costs of open capital markets, and the fact that both China and India have so far been relatively immune from the Asian crisis is cited in favor of the view that the capital account should be kept closed. Two comments: the argument must be about transitional arrangements, since the most advanced countries have open capital accounts; second, I suspect, but cannot of course establish, that with regard to empirical work on the benefits of capital account liberalization, we are just a little behind where we were a decade ago on trade liberalization, when empirical work showing its benefits was widely regarded as highly suspect" (Fischer: 1999, footnote 34$)^{11}$.

If the gains of globalization are concretely little more than wishful thinking by IMF's analysts, just hopes for a better future, its present losses are clearly recognized even by the Fund itself. ${ }^{12}$

According to the Fund, these losses can be minimized (although they cannot be eliminated) in three ways: (1) by correctly sequencing the liberalization process; (2) by having governments to adopt only sound economic policies; and (3) by strengthening domestic financial systems. Sequencing liberalization correctly seems to be easier said than done. As shown by Johnston, Darbar \& Echeverria (1997), economists working for the Fund, there seems to be no magical formula for balanced liberalization. Generally, however, the Fund takes the right sequence to be one in which the circulation of long-term capital and foreign direct investment is liberalized first, and short-term capital flows are liberalized last. Sound economic policies are also a vague requirement. Most of the time, sound policies are just defined as being consistent with stability, but the point of course is to define stability and the means to achieve it. ${ }^{13}$ Fischer (1998: 4), for instance, states that "a sound policy framework promotes growth by keeping inflation low, the budget deficit small, and the current account sustainable." Finally, to strengthen domestic financial systems, two steps are usually suggested: improving financial regulation and supervision; allow entry of foreign banks into the domestic financial system. The opening of domestic banking systems to foreign institutions is assumed to bring to the country their superior expertise in credit matters, their new technologies and the financial support from their headquarters that, one hopes, would be forthcoming in the event of a crisis.

\footnotetext{
11 This statement is, in fact, astonishing. To argue that controls must be "transitional" because advanced countries have open capital accounts seems to be intended to give the false idea that these countries advanced while capital accounts were open! It is either an incredible example of bad penmanship or a deliberate attempt to mislead. What is more astonishing is that even a less than straightforward (to say the least) argument like that cannot avoid the acknowledgement that the benefits of financial globalization are being taken on faith and nothing else.

12 The costs of liberalization result from the vulnerability to shifts in market "sentiment" and the resulting capital flow reversals and balance of payments crises.

${ }^{13}$ This kind of literature exhibits a clear bias to define stability as price stability, instead of, for instance, employment stability.
} 
More recently, perhaps encouraged by the fact that most of the crisis countries chose to persist in the liberalization path or just because the balance of benefits and losses is too doubtful to sustain the Fund's policies, the IMF directors have changed somewhat their language. Now, integration and globalization are no longer presented as possible paths but as irreversible realities. One just cannot backtrack. The choice now is between to stall or to move on. Since stalling would certainly combine the worst of both worlds (it is too soon to reap the full benefits of globalization but too late to try to rebuild controls), the only rational choice is to move on. The real question is no longer if but how. Thus, as put by Camdessus: "my question needs to be rephrased. Recognizing that de facto capital liberalization is under way - and without doubt potentially most beneficial - are we prepared to accept a haphazard, piecemeal and potentially volatile process, or should we try to manage the process in a way that increases economic stability and growth?" (Camdessus: 1999b, my emphasis $)^{14}$.

\section{Structural Adjustments to Promote Financial Globalization}

The new IMF's mission to pursue capital account convertibility has been translated into definite conditionalities even before the amendment to the Articles of Agreement is passed. National economies have to be prepared to accept and promote the free circulation of capital. Lending agreements are the ideal instrument for the IMF to carry on its mission. Cornered by balance of payments crises, client economies have little choice but to accept the liberalizing reforms envisaged by the IMF to push globalization forward. These reforms do not consist just in removing capital and exchange controls. The domestic economy itself has to be prepared to receive capital flows in an orderly way. Stability of capital flows requires, according to the Fund, enforcing tough standards of transparency and good governance ${ }^{15}$. In addition, to minimize the effects of flow reversals, markets should be more flexible and responsive to supply and demand. Removing excess regulations should help

\footnotetext{
${ }^{14}$ See also Camdessus (1999c). On the question whether financial liberalization is reversible or not, it is worth remembering that "the capital account as an independent force became a more general issue in the early 1960 s, after most industrial countries had reestablished convertibility for current account transactions. When countries with the most advanced financial systems began dismantling capital controls, the Fund treated it as a welcome development and thus began to distance the institution further from the view that had prevailed at Bretton Woods. The honeymoon was short. By the mid-1960s, autonomous capital flows were becoming a significant irritant to the major industrial countries. As early as July 1963, the US imposed an "interest equalization tax" to discourage short-term capital outflows, at a time when its current account was in surplus. The United Kingdom also tightened its capital controls around that time. By the late 1960s, many other industrial countries were doing so as well, and the incipient capital account revolution was in full retreat" (Boughton: 1997, 12-3, my emphases). Of course, the situation is different when autonomous capital flows become an irritant mainly to developing, rather than industrial, countries.

15 According to L. Summers, the idea of "generally accepted accounting principles" (GAAP) was "the single most important innovation shaping” American capital markets. Cf. Summers (1999).
} 
capital flows to be allocated in the best way, thus avoiding creating tensions that could in the future become sources of crises. Crises must be prevented by appeasing financial investors' concerns so, hopefully, they will not find reasons to suddenly transfer their financial placements to other economies.

Balance of payments crises are thus nowadays characterized by the Fund as the result of sudden reversals of capital flows ${ }^{16}$ out a country that, for some reason, has lost the confidence of investors (or speculators), both foreign and domestic ${ }^{17}$. The crisis itself is seen as the culmination of imbalances deeply rooted in the economic structure of these economies, in contrast with the crises of the past, that afflicted mainly developed countries. The latter had superficial roots in unbalanced fiscal policies. The current crises of emergent economies are much more difficult to deal with because they originate in more fundamental disequilibria ${ }^{18}$. To solve a crisis of this new kind requires, thus, redesigning the afflicted economy's structures, not just re-dimensioning fiscal expenditures and revenues.

\section{The New Conditionalities}

A conspicuous element in the agreements signed with the IMF in the last few years is the reference to the need to promote structural reforms to count on the Fund's help. Some countries had in fact already initiated financial liberalization on their own. In these cases, the IMF acknowledged the reforms already implemented and pushed for further measures in the same direction. Thus, when stand-by credit offered to Mexico right after the December 1994 crisis was announced, the Fund acknowledged that "the program formulated by the Mexican authorities, and supported by the standby credit, must be seen against the background of Mexico's favorable economic fundamentals and its past record of macroeconomic and structural reforms. " Nevertheless, the stand-by credit was conditional on "consolidat[ing] and extend[ing] this progress [in the area of structural reform] in important ways.

\footnotetext{
16 "The novelty of the financial crises we have seen in the 1990s is that they have been what might be called capital account crises." (Summers, 1999). For a criticism of this notion, see Kregel (1999).

${ }^{17}$ In economies that dismantled capital controls, the problem is not just prevent foreign investors from leaving the country but also domestic investors from fleeing. International investors, that is anybody that can make financial placements in different national economies, not just foreign investors are the relevant actors now.

${ }^{18}$ What made the crisis [in Asia] so different from previous one and so difficult to tackle once it started were the financial vulnerabilities in the banking and corporate sectors, and the speed and size of capital flow reversals that occurred once those vulnerabilities were revealed. The build up of these problems reflected deep-seated weaknesses in corporate governance; ineffective bank supervision; nontransparent relationships among government, banks and corporations; and macroeconomic imbalances evidenced by rising current account deficits and short-term external debt" (Sugisaki, 1999). Shigemitsu Sugisaki is the Deputy Managing Director of the IMF. Camdessus put it like this: "A heavily damaged financial system, a gravely weakened corporate sector, many structural rigidities, not to mention corruption, cronyism, and nepotism, were key among the underlying of the crisis" (Camdessus,: 1999d). See also Camdessus (1999).
} 
"The main thrust of the required 'new progress" was to proceed with the privatization process $^{19}$.

The same acknowledgement is spelled out in Brazil's letter of intent addressed to the IMF on November 13, 1998: "progress in macroeconomic and financial stability has been accompanied by substantial structural reforms". Among these reforms the letter lists the liberalization of trade and financial flows and " perhaps the largest privatization program in history." Nevertheless, the letter goes on to list a long roster of additional reforms promised in exchange for the Fund's credit ${ }^{20}$.

Mexico, Brazil, Argentina and Chile began liberalizing and opening their economies in the late 80 s and early 90 s, long before they actually ran into trouble and needed help from the Fund. In contrast, in the case of the East Asian countries that suffered crises in 1997, more stringent and detailed demands for reforms were made. Structural reforms covering both financial and industrial sectors were set in detail in the letters of intent signed by Korea and Indonesia. In the case of Korea, the letter of intent signed on March 10, 1999, had a 20-page annex listing in minute detail the reforms demanded by the Fund ${ }^{21}$.

The new IMF's longer view was summarized in 1998 by Michael Camdessus. According to the Managing-Director of the Fund, to recover from today's balance of payments crises an emerging economy has to go through a three-tier adjustment process:

"The first tier is to restore stability. As usual, immediate action is needed for countries faced with sudden acute pressure on their balance of payments. The second tier is to improve soundness. Lost confidence, especially in domestic financial and corporate systems, has to be restored through fundamental institutional changes. The third tier is to boost efficiency. The approach of 'managed development' underlying economic policy, characterized by mechanisms that interfered with market allocation of resources, has become increasingly out of tune with the rigorous demands of our globalized economy." (Camdessus: 1998)22

Tier one consists in raising interest rates to convince international investors to keep their capital in the country and in cutting fiscal deficits (or increasing surplu-

\footnotetext{
${ }^{19}$ Quotations from IMF, Press Release 95/10, February 1, 1995, in the IMF website. Almost ten years after adoption of its successful stabilization plan and promoting deep "structural" reforms, Argentina was still as dependent on volatile capital flows as always and, thus, on the endorsement of its policies by the IMF. In its January 1999 letter of intent addressed to the Fund, the Argentine government announced new additional structural reforms, including the adoption of a "Fiscal Responsibility Law" similar to the one also accepted by the Brazilian government in its deals with the IMF. See Argentina's Policy Memorandum, January 11, 1999, in the IMF website.

${ }^{20}$ Brazil, Memorandum of Economic Policies, November 13, 1998, in the IMF website.

${ }^{21}$ Available in the IMF website.

22 The strategy is presented in somewhat more detail in Sugisaki (1999).
} 
ses) to signal the disposition to make all required sacrifices to accept market discipline. Tier two refers to initiatives such as cleaning the financial system of nonviable institutions, putting an end to favors to private firms, streamlining government apparatuses, etc. Finally, tier three means transforming government from an active player in the economy into a magistrate, a regulator and guarantor of an economic order that allows for the free interplay of private agents. It is not, thus, just a question of balancing external trade transactions anymore. The IMF has explicitly assumed the task of shaping economies to fit in a globalized new financial order.

\section{IMPLICATIONS FOR CLIENT ECONOMIES OF THE NEW ROLE OF THE IMF}

The changes in the role played by the IMF described in the previous section mean that a country that currently appeals to the support of the Fund has to be prepared to undergo a much deeper transformation of its economic structure than in any time in the past. The IMF should still care for stable exchange rates, according to the Articles of Agreement that rule its behavior. Stable exchange rates, however, have to be achieved in a framework of increasingly free international capital flows that are currently much larger than international trade flows. As a result, exchange rates are currently more important as an element of asset prices than of price of goods, and asset prices are intrinsically much more volatile than prices of goods. Thus, to keep exchange rates stable in conditions of free capital movements requires much more effort by domestic policymakers than was necessary before. On the other hand, as noted earlier, international capital flows nowadays are mainly private and consist of portfolio investments. This type of investment is notoriously short-termist and volatile, causing any possible equilibrium that an economy can reach exceedingly fragile ${ }^{23}$.

Under these circumstances, tier one of Camdessus' recovery strategy can last forever. An emerging country with open capital and current accounts are always subject to sudden reassessments of risks and prospective gains that may lead to reversals of capital flows and balance of payments crises. To follow the IMF's strategy, these countries have to be prepared to react in such a way as to regain the investors' good will, by raising interest rates to the extent necessary to lull the investors' disquietudes. The recurrence of episodes of interest rate increases tends to strengthen bearish sentiments as to future interest rates, keeping them higher than otherwise ${ }^{24}$. In this context, investments in real capital assets are penalized and

\footnotetext{
${ }^{23}$ For a discussion of new trends in the international financial system, see Carvalho (1997).

${ }^{24}$ In theory, floating exchange rates should eliminate this problem and the need to appeal to increases in interest rates. In reality, however, few countries are prepared to see their currencies suffer the sharp changes in external value that would take place in a world as the one just described. It has been general practice that governments will try to limit fluctuations around a desired trend value or at least limit the
} 
trend growth rates reduced. Economies appealing to frequent increases in interest rates can even exhibit positive growth in calmer periods, but output is more likely to grow by reduction of idle capacity since investments are likely to be reduced. The resulting picture is a sequence of stop and go episodes along a declining longterm trend.

It is important to note that this is not a temporary shortcoming of this kind of strategy. Vulnerability to sudden capital outflows is an intrinsic element of a financially integrated world as devised by the IMF. This is a permanent situation and so are the risks associated with it ${ }^{25}$.

Besides this potential mousetrap that may keep economies indefinitely in the "short-term", adhering to the IMF's strategy also means important losses of degrees of freedom in what respects growth policies. Any policy that can be construed as interventionist, be it industrial policy or commercial policy, or whatever, will be branded as populist and will generate suspicion in the financial community. Again, in the absence of controls and restrictions, financial investors will be able to veto these policies by withdrawing their placements from the country, causing balance of payments crises and forcing a retreat by the deviating government to the ranks of the well-behaved. This is precisely what the IMF means by being disciplined by the market, one of the hallmarks of financial globalization ${ }^{26}$.

In sum, in contrast with the conditionalities of the past, that consisted only in measures to redimension fiscal deficits and revenues, current conditionalities seek to change structures and to close options that governments could want to adopt in the future and that could offend the "sentiment of the market". Policies that intensify financial integration are designed to eliminate the possibility of pursuing policies detrimental to what financial investors consider their interest in order to achieve yet undefined, and according to many economists, just unreachable, benefits in an uncertain future.

\section{CONCLUSION}

The IMF has dramatically changed the way it defines its own mission in the 1990s. From being the manager of an international monetary system based on fixed exchange rates and supplier of short-term liquidity to countries undergoing tem-

amplitude of fluctuation in any given period. Acting by the rules book, this should be done through changes in interest rates.

${ }^{25}$ Again, in the words of Camdessus: "Further, countries that successfully attract large capital inflows must also bear in mind that their continued access to international capital is far from automatic, and the conditions attached to that access is not guaranteed. The decisive factor here is market perception: whether the country's policies are deemed basically sound and its economic future, promising" (Camdessus: 1995, my emphasis).

${ }^{26}$ As clearly put by Camdessus: "the globalization of world's financial markets has sharply reduced the scope for governments to depart from traditional policy discipline" (Camdessus: 1995, my emphasis). 
porary current account deficits to becoming the crusader of the brave new world of global financial integration, the Fund has taken its task to be to reform national economic structures to prepare them for the new liberal financial order. As a result, the impact of its policies for the client countries became much deeper than in the past. Its conditionalities no longer set just quantitative goals, like reducing fiscal expenditures or contracting the supply of credit to bring aggregate demand into balance with supply. Qualitative targets, set in terms of structural reforms, passing of new legislation and abrogation of laws, regulations and even constitutional dispositions seen as contradictory "with the rigorous demands of our globalized economy", as put by Camdessus, quoted above, became routine demands among IMF conditionalities.

If, on the one hand, the impact on client economies is now deeper than before, it also lasts much longer. In fact, potentially it may last forever. Short-term measures to react to the threat of capital flight do not reduce external vulnerability. On the contrary, it crystallizes a situation in which the possibility of withdrawal of financial placements from the afflicted economy becomes a Damocles' sword hanging over the economy. Long-term policies, on the other hand, are designed to preclude any interventionist adventure by national governments that could jeopardize “Investors' sentiment”.

Although the IMF find many developed Western economies wanting in terms of market flexibility ${ }^{27}$, developing countries run particularly large risks when accepting its strategy and its goals. These economies are not only much likelier to suffer deficits in their foreign transactions but they are also much more vulnerable to changes in capital flows given their small size relatively to the size of international capital flows. Relatively small adjustments in the portfolio of international investors can cause large disruptions in the capital accounts of developing countries, increasing the potential disturbances to which the latter are subject.

The main question, then, is why? Why accept all these risks? Why accept the loss of freedom in the setting of policy priorities both in the short and in the longterm? The IMF seems to take benefits from globalization on faith, since the evidence on the gains from integration is so weak. Risks are too big, however, for developing countries to make such a bet, even if faith in the general efficiency of markets is shared. It is unavoidable the thought that if the IMF is willing to idealize the working of financial markets, it is much less reasonable to push developing economies toward a goal the benefits of which are in reality so doubtful.

${ }^{27}$ See, e.g., the examination of the causes of current unemployment in Western Europe in IMF (1999). 


\section{REFERENCES}

BOUGHTON, J. (1997) "From Suez to Tequila: The IMF as Crisis Manager", IMF Working Papers, $97 / 90$.

CAMDESSUS, M. (1995) “The IMF and the challenges of globalization - The Fund's evolving approach to its constant mission: The case of Mexico", IMF website.

(1995b) "Drawing lessons from the Mexican crisis: preventing and resolving financial crises the role of the IMF", IMF website.

(1998) "Crisis in emerging market economies: the road to recovery", IMF website.

(1999) "Looking beyond today's financial crisis: moving forward with international financial reform”, IMF website.

(1999b) "Governments and economic development in a globalized world", IMF website.

(1999c) "Economic prospects for the Americas under a new financial architecture", IMF website.

(1999d) "Preventing and resolving financial crises: the role of the private sector", IMF website. CARVALHO, F. (1997) "Financial innovation and the Post-Keynesian approach to the 'process of capital formation'”, Journal of Post Keynesian Economics, 19 (3), spring.

FISCHER, S. (1998) "Capital account liberalization and the role of the IMF", in S. Fischer et al., Should the IMF Pursue capital account convertibility?. Princeton, Essays in International Finance.

(1999) "On the need for an international lender of last resort", IMF website.

GREENWALD, B. \& STIGLITZ, J. (1984) "Informational imperfections in capital markets and macroeconomic fluctuations”, American Economic Review.

INTERNATIONAL MONETARY FUND, World Economic Outlook, May 1999.

JOHNSTON, R., DARBAR, S. \& ECHEVERRIA, C. (1997) "Sequencing capital account liberalization: lessons from the experiences in Chile, Indonesia, Korea and Thailand", IMF Working Paper $97 / 157$.

KEYNES, J. M. The Collected Writings of John Maynard Keynes, vol. 25. London, MacMillan, referred to as CWJMK 25.

The Collected Works of John Maynard Keynes, vol. 26. London, MacMillan, referred to as CWJMK 26.

KREGEL, J. (1999) “Was there an alternative to the Brazilian crisis?”, Revista de Economia Política, 19 (3), jul.-sep.

MASSON, P. \& MUSSA, M. (1997) “The Role of the IMF”, Pamphlet Series n. 50, IMF.

RODRIK, D. (1998) "Who needs capital account convertibility?" in S. Fischer et al., op. cit.

SUGISAKI, S. (1999) "Economic crisis and recovery in Asia and its implications for the international financial system”, IMF website.

SUMMERS, L. (1998) "Remarks before the International Monetary Fund”, Treasury News, RR 2286. (1998b) "Repairing and rebuilding emerging market financial systems", Treasury News, RR 2671.

(1998c) "The role of multilateral institutions in preserving international financial stability", Treasury News, RR 2226.

(1999) "Riding the storm: Latin America and the global financial market", Treasury News, RR 3122. 